\title{
Incorporating the Hybrid Learning Model into Minority Education at a Historically Black University
}

\author{
Dr. Nicole A. Buzzetto-More \\ University of Maryland Eastern \\ Shore, Princess Anne, MD, USA
}

Nabuzetto-more@umes.edu

\author{
Dr. Retta Sweat-Guy \\ Fayetteville State University, \\ Fayetteville, NC, USA
}

\section{Executive Summary}

Proponents of hybrid learning proclaim it to be an effective and efficient way of expanding course content that supports in-depth delivery and analysis of knowledge (Young, 2002) and increases students satisfaction (Campos \& Harasim, 1999; Dziuban \& Moskal, 2001; Rivera, McAlister, \& Rice, 2002; Wu \& Hiltz, 2004). In the years to come, hybrid learning is poised to cause a paradigm shift in higher education (Allen \& Seaman, 2003; Lorenzetti, 2005; Young, 2002).

Graham B. Spanier, president of Pennsylvania State University, was quoted in Young (2002) as saying that hybrid learning presents "the single-greatest unrecognized trend in higher education today." This benefits of online and hybrid learning have been recognized by the State of Maryland. In a move to stimulate the use of alternative delivery methods, the regents of the University System of Maryland instituted a policy in 2005 that all students take on average 12 of their credits through out-of-classroom experiences and other nontraditional means. Included in the regents' definition of out-of-classroom experiences are e-learning, internships, student teaching, and a host of other activities. Diana G. Oblinger, vice president of Educause, was cited in Lorenzetti (2005) as saying that the Maryland system is recognizing that some online learning is an enhancement to students' higher-education learning experiences even when those students are full-time oncampus residents. She asserted that the Maryland initiative indicates, and will result in, tangible growth in the hybrid learning model.

This paper presents the findings of a study that examined student perceptions of hybrid business courses at a historically black university that operates within the University System of Maryland. Founded in 1886, the University of Maryland Eastern Shore (UMES) is a historically black, 1890 land grant institution and a member of the thirteen-campus University System of the State of Maryland.

Material published as part of this journal, either on-line or in print, is copyrighted by the Informing Science Institute. Permission to make digital or paper copy of part or all of these works for personal or classroom use is granted without fee provided that the copies are not made or distributed for profit or commercial advantage AND that copies 1) bear this notice in full and 2) give the full citation on the first page. It is permissible to abstract these works so long as credit is given. To copy in all other cases or to republish or to post on a server or to redistribute to lists requires specific permission and payment of a fee. Contact Publisher@InformingScience.org to request redistribution permission.
Albeit a late entry into the world of online learning, UMES has made significant strides over the last 4 years, including the adoption of WebCT, the online course management system employed by the University System of Maryland. Currently, UMES offers copious numbers of web-enhanced courses, a number of hybrid courses, and a smattering of fully online courses. 
The population for this study was chosen after an exhausting literature review revealed that there was a lack of substantial research that focused specifically on the perceptions of African American college students with respect to e-learning. Additionally, it provides critical insight to the opinions of a population that statistically falls within the diminutive end of the digital divide.

During the course of this study a survey was administered to 178 students who had completed either a business communications or business ethics course using the WebCT course management system. The hybrid learning environments created for these two required courses included:

PowerPoint lecture notes; a glossary of key terms and definitions indexed alphabetically and by unit of study; relevant links to external websites; supplemental handouts; self-checks; quizzes; an online discussion section; and individual mailboxes.

The study spanned four semesters, beginning in the fall of 2003 and concluding in the spring of 2005. Data was collected through the administration of a survey using the Zoomerang online survey service. The survey instrument was comprised of Likert scale, multiple choice, and openended questions and was analyzed using SPSS.

The results of this paper suggest that the use of course websites in higher education increases students' course satisfaction. Students responded that they were satisfied with their use of WebCt, enjoyed the online portion of the course, and considered the use of WebCt a motivating tool. The students overwhelmingly responded that they were interested in enrolling in future hybrid learning experiences; however, approximately half said they would take a fully online course in the future. The findings of this study are complementary with the results of similar studies conducted at majority institutions.

This study has indicated that hybrid learning has a positive future in minority education; however, more research is needed. As a result, a large-scale more in-depth research study was launched in the Fall of 2005 and is ongoing. Courses have been be redesigned with mandatory and instructorled discussions, and expanded content and resources. New instrumentation has been developed that asks more in-depth questions regarding the individual learning components and comparisons will be made between fully online, hybrid, and web-assisted courses.

Keywords: Digital divide, minority education, hybrid learning, e-learning, asynchronous learning

\section{Background}

In 2005, the regents of the University System of Maryland instituted a policy in 2005 that all students enrolling in a Maryland State University as of the fall of 2007 take on average 12 of their credits through out-of-classroom experiences and other nontraditional means. The definition of out-of-classroom experiences includes: e-learning, internships, student teaching, and a host of other activities.

Founded in 1886, the University of Maryland Eastern Shore (UMES) is a historically black, 1890 land grant institution and a member of the thirteen-campus University System of the State of Maryland. The student body is approximately 3,700, with $10 \%$ of the enrollment representing graduate students. UMES is located in a rural region and is the most affordable four-year institution of higher education in the state. With the institution's inexpensive tuition and minimal enrollment criteria, the university attracts a large number of students from a lower socio-economic background than is found in colleges and universities across the state. The Department of Business Management and Accounting is one of the largest departments on campus. The department has approximately 420 majors, offering programs that include Business Management, Marketing, Accounting, and Business Education. The Department of Business was chosen because of its size and adequate socio-economic representation of the UMES student body. Additionally, a histori- 
cally black institution was chosen due to the lack of substantial research that focused specifically on the perceptions of African American college students with respect to e-learning.

WebCt has been adopted as the course management system of choice by the University System of Maryland. UMES began integrating WebCt into their curriculum in 2001. Currently, UMES offers a large number of web-enhanced courses, a few dozen of hybrid courses, and a handful of fully online courses.

\section{Literature Review}

The higher-education classroom has undergone radical reformations in the last decade as a result of technological development, causing academicians across the globe to recognize the importance of technology in higher learning. Technology has illustrated that the classroom does not need to be the nucleus of learning, as networked multimedia are able to extend the teaching and learning experience (McClintock, 1999).

Course websites have proved to be an effective means of delivering learning materials, with students responding positively to the quality resources they make available. Wernet, Olliges, and Delicath (2000), who surveyed students who used WebCT in a social work course, found that all of the respondents considered the online course materials beneficial to their overall learning experiences.

The movement from the traditional classroom to web-enabled learning has been explained as a move from a behaviorist methodology to a constructivist one (Lewis, MacEntee, DeLaCruz, Englander, Jeffrey, Takach, Wilson, \& Woodall, 2005). Koohang and Harman (2005) assert that elearning by its very nature is rooted in constructivist ideology, where knowledge acquisition is a self-directed activity that is facilitated by an instructor. They draw correlations between elements inherent in both constructivism and e-learning including: collaboration, social discourse, problem solving, exploration, anchored instruction, critical thinking, the revisiting of information in multiple perspectives and representations, intellectual discourse, knowledge construction, and scaffolding.

Much of the instructional-technology-based research that has been conducted in the past decade focused on the examination of fully online learning experiences. Significantly less attention has been paid to the blended, or hybrid, learning format. Hybrid courses blend face-to-face interaction with online learning and customarily involve the delivery of curricular materials, access to resources, submission of assignments, and online discussions that may be asynchronous or synchronous in nature. Although the hybrid format has received significantly less attention then its fully online cousin, Allen and Seaman (2003) found that the rate of growth of hybrid courses is exceeding that of fully online courses. They also forecasted that hybrid learning will make a sizable impact on the future of higher education.

Hybrid learning environments have been shown to address the frustrations and limitations resulting from the separation of tutor and tutee commonly found with fully online education (Hodges, 2004). John R. Bourne, a professor of electrical and computer engineering at Franklin W. Olin College of Engineering and editor of the Journal of Asynchronous Learning Networks, was quoted in Young (2002) as having said, "Within five years, you'll see a significant number of classes that are available in a hybrid fashion.... I would guess that somewhere in the 80- to 90percent range of classes could sometime become hybrid."

The benefits of hybrid learning are increasingly being realized as an escalating number of courses demonstrate the blended format to be a viable, even exemplary, mode of instruction. Enrollment in hybrid courses remains high, and the reported rates of student satisfaction indicate that learners by and large view such courses favorably. Campos and Harasim (1999) found that the majority of 
students surveyed preferred mixed-mode learning experiences. Research by Dziuban and Moskal (2001) indicated that hybrid courses yielded success rates equal to and, in many cases, greater than their fully online or face-to-face counterparts. Wu and Hiltz (2004) found that hybrid courses that utilized asynchronous means of communications improved students' perception of learning. According to Bhatti, Tubaisahat, and El-Quawasmeh (2005) who examined the perceptions of female students in regards to hybrid learning, student satisfaction increased with mixed-mode learning while the students' dependency on the instructor for assistance decreased. They explained that online materials provided students with the resources to seek out answers independent of the instructor. Rivera, McAlister, and Rice (2002), who surveyed student satisfaction among the three modes of learning (face to face, fully online, and hybrid), found that student satisfaction was the highest with the hybrid learning model and that test scores were the same for all three methods of delivery. The hybrid teaching method may eventually become the norm in higher education. Young (2002), who examined hybrid and fully online teaching at several universities, concluded that among the three modes of instruction (face to face, fully online, and hybrid) the hybrid model posed the most substantive benefits for teaching and learning.

Are hybrid courses evaluated differently then traditional and fully online learning experiences? Carnevale (2000) found that regardless of the learning format, students took into consideration knowledgeable instructors, interaction with instructors, and additional features that create a sense of community when evaluating courses for merit. The importance of technological preparedness, willingness, and the overall mindsets of students has also been acknowledged by educators as playing a crucial role in both the hybrid and online learning equations. Sanders and MorrisonShetlar (2002) cited the importance of student attitudes toward technology as a significant determining factor in the educational benefits of online learning resources and experiences.

Traditionally, historically black colleges and universities have lagged behind majority institutions in the incorporation of e-learning into their curriculum. At the same time, and even with a new century upon us, the digital divide remains a significant concern in the United States, with race/ ethnicity, income level, and education contributing to inequalities with use of computers and reliable and expedient access to the internet (Morgan \& VanLegen, 2005). Fifteen and a half percent of individuals with less than a high school education use the internet compared to $44.5 \%$ of those with a high school education, and $84.5 \%$ of college graduates; concurrently, as income levels increase so does the likelihood of computer and internet usage (National Telecommunications and Information Administration, 2004). The ways that students of different groups benefit from technology facilitated instruction is also divided with minority students from lower socio-economic backgrounds more likely to experience drill and practice, while white students from higher socioeconomic backgrounds more likely to benefit from technologies that help build, and require the use of, higher order thinking skills. (Jackson, Ervin, Gardner, \& Schmitt, 2001). According to the National Center for Education Statistics, $77 \%$ percent of Caucasians have home computers compared to $41 \%$ of blacks and Hispanics; at the same time, white students are twice as likely as blacks and Hispanics to use a computer for school assignments (Institute of Education Sciences, 2003). A recent study by Morgan and VanLengen (2005) has shown that increases in income and education level raise the likelihood of home computer usage and that white, Asian Americans, and mixed race people are more likely to engage in home computer use then black, Native American, and Hispanics.

E-learning has been presented by many as a means of equalizing access to quality education and there are an abundance of academics who extol the benefits of web-enabled learning (McClintock, 1999). The hybrid learning model has become a permanent fixture on our educational landscape and it is slowly rising in popularity at minority institutions. The question therefore being researched in this study is, Will student perceptions of hybrid courses at a historically 
black university be reviewed by minority students propitiously, similar to the findings of studies conducted at majority institutions?

\section{Research Methodology}

In order to examine perceived student satisfaction of hybrid courses among a predominantly minority population, a study was conducted at a historically black university. A literature review yielded some interesting studies that examined student perceptions of hybrid learning experiences; however, a detailed search that sought out meaningful published research focusing on African American students and online/hybrid learning in higher education yielded no substantive findings. As a result, it became eminently clear that this study was both necessary and belated.

At the outset of this study, hybrid learning environments were created for two business courses: business ethics and business communications. These courses are requirements for business majors and are taken primarily by students with sophomore or junior standing. The WebCT course management system was utilized, and both courses included PowerPoint lecture notes; a glossary of key terms and definitions indexed alphabetically and by unit of study; relevant links to external websites; supplemental handouts; self-checks; quizzes; an online discussion section; and individual mailboxes.

The study spanned four semesters, beginning in the fall of 2003 and concluding in the spring of 2005. The instrumentation used was a survey that contained a mixture of Likert scale, multiple choice, and open-ended questions. The survey was made available online through Zoomerang, an independent survey service. An external link to the Zoomerang site was placed on the course websites. Students were instructed that their participation in the survey was a required activity; however, their individual responses to questions were anonymous.

SPSS was utilized during the data analysis process. Likert scale questions were evaluated based on mean, mode, minimum and maximum responses, standard deviation, and percentages. Multiple choice questions were evaluated on a percentage basis. Additionally, cross-tabulations were run with respect to several questions in order to determine relationships.

In total, 178 students responded to the questionnaire. The majority of participants were minorities, with 73\% being African or African American, 8.4\% Asian, 2\% Caucasian, .6\% Hispanic, and $16 \%$ claiming other ethnicity. Ninety-five percent of the students were between the ages of 18 and 21 . The number of females responding to the questionnaire outnumbered males, with $82 \%$ of the participants female and $18 \%$ male.

Participants were asked to self-select a ranking for their level of computer expertise. Computer proficiency was a commonality among participants, with the majority of participants, $86.5 \%$, having responded that they were intermediate computer users. An additional $13 \%$ categorized themselves as computer experts, while less than $1 \%$ considered themselves computer novices. Prior experience with course websites was also frequent, with $63 \%$ of the respondents answering that they had previous experience with online learning.

\section{Findings}

The responses indicated that students were pleased with their use of WebCT. When asked to rate their overall satisfaction with WebCT, the students overwhelmingly answered that they were satisfied, with $92 \%$ noting agreement. The literature reviewed supports the use of WebCT as a supplement to learning.

Interest in future hybrid learning experiences was examined and $91 \%$ of the respondents said they would take another web-supported course in the future. Interestingly, although the respondents 
overwhelmingly indicated a willingness to enroll in further hybrid learning experiences, a smaller majority, $53 \%$, said they would take a fully online course in the future. This is reflective of the larger literature as expressed by Berube, Murray, and Schultz (1999) who suggest that there exists a greater acceptance of the online mode of instruction as an adjunct to learning.

When prompted to respond to the statement "I enjoyed the portion of the course presented on WebCt," a substantial $89.3 \%$ percent agreed. The respondents were equally divided between "strongly agree" and "agree." With respect to WebCt as a motivating tool, the students largely reported that the addition of WebCt stimulated their desire to learn, with $70.8 \%$ reporting agreement, $24.7 \%$ neutrality, and $4.5 \%$ disagreement. These findings are similar to recent studies have found that the Web component had a positive effect on student learning and satisfaction (Sanders \& Morrison-Shetlar, 2001; Wernet, Olliges \& Delicath, 2000).

Proponents of web-based teaching and learning suggest that providing useful and relevant information about the course content correlates positively with student satisfaction and participation (Sanders \& Morrison-Shetlar, 2001). Numerous studies have illustrated the benefits of course websites as a supplement to face-to-face learning. In the current study, students were provided with web-based resources that served as reinforcements such as lectures notes, handouts, discussions, external websites, and quizzes. Regarding the quantity of their learning experiences, participants in this study almost universally cited their satisfaction with WebCT as a supplement to their traditional face-to-face experiences, with 93.8\% agreeing. Additionally, course websites have consistently been shown to be an effective means of delivering course content. It came as no surprise, therefore, that participants reported high levels of satisfaction with regard to the qualityof the online materials and activities, with $69 \%$ agreeing, $17 \%$ neutral, and $14 \%$ disagreeing.

Course websites are frequently used by instructors and students as a means of stimulating communications and interactions. Based on current research, interaction in a web supplemented course yields mixed reviews. However, a significant number of studies revealed increased interaction among students and with instructors (Carswell, Thomas, Petre, Price, \& Richards, 2000; Lesh, Guffey, \& Rampp,, 2000; Westbook, 1999). When asked to respond to the statement "The WebCT portion allowed for social interaction," 53\% agreed, $27 \%$ were neutral, and 20\% disagreed. The reliability; however, of WebCT as a means of communications was supported with $82.5 \%$ agreement, $12 \%$ neutrality, $5.5 \%$ disagreement. It is important to note that although a discussion section and mailbox were used for student initiated questions and answers and informal interactions, no formal discussions initiated or led by an instructor were built into the course curriculum. Table 1 presents student responses to scaled questions on a percentage basis as well as standard deviation, mean, and number of respondents. Table 2 presents the responses to the yes of no questions based on a percentage distribution .

\section{Table 1: Student's Perceptions of WebCt}

Response Category: $\mathrm{SA}=$ Strongly Agree, $\mathrm{A}=\mathrm{Agree}, \mathrm{N}=$ Neutral, $\mathrm{D}=$ Disagree, $\mathrm{SD}=$ Strongly Disagree

\begin{tabular}{lclllllll}
\hline & SA & A & N & D & SD & STD & Mean & N \\
\hline $\begin{array}{l}\text { I was satisfied with the } \\
\text { overall experience using }\end{array}$ & $42 \%$ & $50 \%$ & $5 \%$ & $2 \%$ & $1 \%$ & .761 & 4.29 & 178 \\
$\begin{array}{l}\text { WebCT } \\
\begin{array}{l}\text { I enjoyed the portion of } \\
\text { the course on WebCt }\end{array}\end{array}$ & $42.7 \%$ & $46.6 \%$ & $6.7 \%$ & $3.4 \%$ & $0.6 \%$ & .779 & 4.28 & 178 \\
$\begin{array}{l}\text { The WebCT portion } \\
\text { stimulated my desire to } \\
\text { learn }\end{array}$ & $28.7 \%$ & $42.1 \%$ & $24.7 \%$ & $3.9 \%$ & $0.6 \%$ & .862 & 3.94 & 178 \\
\hline
\end{tabular}




\begin{tabular}{|c|c|c|c|c|c|c|c|c|}
\hline $\begin{array}{l}\text { I was satisfied with } \\
\text { WebCt in regards to the } \\
\text { quantity of my learning } \\
\text { experience }\end{array}$ & $37 \%$ & $57 \%$ & $5 \%$ & $1 \%$ & $0 \%$ & .616 & 4.30 & 178 \\
\hline $\begin{array}{l}\text { I was satisfied with } \\
\text { WebCt in regards to the } \\
\text { quality of my learning } \\
\text { experience }\end{array}$ & $37 \%$ & $54 \%$ & $8.4 \%$ & $0.6 \%$ & $0 \%$ & .636 & 4.28 & 178 \\
\hline $\begin{array}{l}\text { WebCT portion allowed } \\
\text { for social interaction }\end{array}$ & $17.4 \%$ & $35.4 \%$ & $27 \%$ & $15.7 \%$ & $4.5 \%$ & 1.090 & 3.46 & 178 \\
\hline $\begin{array}{l}\text { WebCT provided a reli- } \\
\text { able means of communi- } \\
\text { cation }\end{array}$ & $33.1 \%$ & $49.4 \%$ & $12 \%$ & $4.5 \%$ & $1 \%$ & .852 & 4.09 & 178 \\
\hline
\end{tabular}

Table 2: Student Responses to Yes or No Questions

\begin{tabular}{lll}
\hline & Yes & No \\
\hline Was this your first web-supported course & $37 \%$ & $63 \%$ \\
$\begin{array}{l}\text { Would you enroll in another course that is } \\
\text { web-supported }\end{array}$ & $91 \%$ & $8 \%$ \\
$\begin{array}{l}\text { Would you take a course that is fully online } \\
\text { without face-to-face instruction }\end{array}$ & $53 \%$ & $47 \%$ \\
\hline
\end{tabular}

After running a number of cross-tabulations, a few interesting correlations were drawn which are expressed in Table 3 and 4 respectively. Although $98 \%$ of the respondents who had taken a websupported course in the past said they would take one again, the figure dropped to $79 \%$ among those who were taking such a course for the first time. Likewise, the study conducted by Liu, Reed, and Phillips (1992) found that first-time students of web-supported instruction experienced more anxiety than those with previous experience.

When overall satisfaction was cross-tabulated by computer expertise, there were no significant findings, illustrating that intermediate and expert computer users were equally satisfied with their learning experiences. These findings could be explained by the quality and quantity of useful and relevant information posted to the Web, thereby replacing an expectation of technological sophistication. The web portion of the course was delivered using standard tools made available through the Web-CT course management software package. The standard tools help students assess their mastery of course material via online quizzes, access their grades, track course requirements, and download chapter lecture notes. Additionally, the findings support the belief that students are being exposed to computers before entering college. Many studies that observe significant differences cite computer-related experience as a key factor (Martinex \& Mead, 1988; Moon, 1994; Price \& Winiecki, 1995; Smith \& Necessary, 1996).

When overall satisfaction was cross-tabulated by gender, women expressed greater satisfaction, at $94 \%$, than did men, at $81 \%$. Satisfaction appeared to have virtually no relationship to a student's desire to take future online courses. The results were not surprising given the academic performance of females versus males at other benchmark institutions. The study conducted by Sanders \& Morrison-Shetlar (2001) revealed similar findings. In contrast, several studies found that males have a more positive attitude than females because they lack computer experience (Smith \& Necessary, 1996). 
Additionally, when overall satisfaction was cross-tabulated with a student's willingness to take a fully online course, $94 \%$ of the participants who said they would take an online course in the future expressed satisfaction, compared to the $89 \%$ who said they would not take an online course in the future. The findings support the assertion by others that when designing instruction for web-supported courses, the web component must be successful in reaching all types of learners and diverse student populations in order to achieve overall student satisfaction (Sanders \& Morrison-Shetlar, 2000; Smith \& Necessary, 1996; Wernet et al., 2000).

\section{Table 3: Cross-tabulations}

\section{Students' perceived satisfaction correlated with willingness to enroll in another Web- supported class, willingness to take a fully online course, and by gender respectively.}

\begin{tabular}{|c|c|c|c|c|c|c|}
\hline \multirow{2}{*}{$\begin{array}{l}\text { Overall satisfac- } \\
\text { tion with your } \\
\text { experience using } \\
\text { WebCt }\end{array}$} & \multicolumn{2}{|c|}{$\begin{array}{l}\text { Would you enroll in another } \\
\text { course that was web- } \\
\text { supported }\end{array}$} & \multicolumn{2}{|c|}{$\begin{array}{l}\text { Would you take another course } \\
\text { that is fully web-based w/out } \\
\text { face-to-face interaction }\end{array}$} & \multicolumn{2}{|c|}{ Gender } \\
\hline & Yes & No & Yes & No & Female & Male \\
\hline SA & $43 \%$ & $32 \%$ & $49.4 \%$ & $33 \%$ & $43.8 \%$ & $31 \%$ \\
\hline A & $50 \%$ & $44 \%$ & $44 \%$ & $56 \%$ & $50 \%$ & $50 \%$ \\
\hline $\mathbf{N}$ & $5 \%$ & $6 \%$ & $4.2 \%$ & $6 \%$ & $4.7 \%$ & $6.2 \%$ \\
\hline D & $2 \%$ & $6 \%$ & $2 \%$ & $2.4 \%$ & $1.3 \%$ & $6.2 \%$ \\
\hline SD & $0 \%$ & $12 \%$ & $0 \%$ & $2.4 \%$ & $0 \%$ & $6.2 \%$ \\
\hline Response \# & 95 & 83 & 162 & 16 & 146 & 32 \\
\hline
\end{tabular}

Table 4: Cross-tabulation Students' perceived satisfaction correlated by computer expertise.

\begin{tabular}{lccc}
\hline & \multicolumn{3}{c}{ Computer Expertise } \\
\hline $\begin{array}{l}\text { Overall satisfaction with } \\
\text { your experience using }\end{array}$ & Novice & Intermediate & Expert \\
WebCt & & & \\
Very Unsatisfactory & $0 \%$ & $0.6 \%$ & $0 \%$ \\
Unsatisfactory & $0 \%$ & $1.2 \%$ & $0 \%$ \\
Neutral & $100 \%$ & $13 \%$ & $22 \%$ \\
Satisfactory & $0 \%$ & $49.3 \%$ & $43 \%$ \\
Very Satisfactory & $0 \%$ & $36 \%$ & $35 \%$ \\
\hline Response \# & 1 & 154 & 23 \\
\hline
\end{tabular}

The questionnaire included several open-ended questions. We analyzed and categorized the responses thematically. Participants were asked to describe areas that they would rate unsatisfactory. The major theme that emerged from this question focused on technical reliability issues, as well as the time span of assignment availability (an aspect dictated by the instructor). The students' responses to this question included:

- "The self-test and glossary not staying up for long."

- "It would have been better if there was a way to keep the chapter self-tests available longer." 
- "The only thing that I would rate unsatisfactory is when the computers shut down and the Internet was not accessible."

- "As an overall system I did not like WebCt, it just seemed to take a little bit of the fun out of the human side of learning."

- "I think everything is satisfactory."

- "The class is a great experience for people in the business world."

Participants were asked whether they would take a fully online course without face-to-face interaction and then to provide commentary on their answers. The students who responded in the negative primarily cited the lack of interpersonal interactions. Conversely, the students who answered in the positive tended to discuss the personalization of interactions, the ability to ask and receive answers to questions, and the ability to work at one's own pace. Sample students' responses to the question included:

- "No, you need interaction with students."

- "No. I like the human interaction with the classroom."

- "I feel better in the classroom but it would depend on the course."

- "No. I like to be face to face with my instructor to get a better understanding of the material."

- "No. Sometimes face to face instruction is quicker and easier."

- "Yes. The students' would be able to set their own pace."

- "Yes. I feel that with WebCT questions could be addressed and answered better without disruption."

- "Yes....increased interactions with WebCt"

\section{Contributions}

This study provides initial research on a population that has previously not received sufficient focus. This paper builds on the findings of a number of studies that have examined student satisfaction of hybrid learning at majority institutions. This study may be expanded and used as inspiration for future studies that focus more specifically on student perceptions of individual course components.

Responses to this study have shown that students perceive the use of WebCT as a course enhancement positively. The results mirror the findings of similar studies conducted at majority institutions. These results have helped propel an ongoing discussion on the future of online learning at UMES. At a university where many students arrive ill-prepared for higher education, online learning is aggressively being examined as a viable means for educational empowerment, increasing professional preparedness, and building communications skills.

\section{Limitations of This Study}

The most significant limitation of this study is that the courses did not contain instructor-led and formally assigned and required asynchronous discussions. The discussions that occurred throughout the courses were student initiated and frequently focused on the asking and answering of questions among students and between students and the instructor. This limitation most likely 
influenced student responses to the questions regarding the use of WebCt for social interaction and as a means of communication.

The gender imbalance is another limitation of this study. The majority of the respondents were female although course enrollment was equally distributed among gender lines. The authors can only speculate about this imbalance. Traditionally, female students at historically black universities surpass their male counterparts with significantly higher graduation rates. When the grade distribution for the course was examined along with class participation, the authors noticed that across the board the female students had consistently outperformed their male counterparts with respect to both academic performance and participation.

\section{Summary and Future Research}

The results of this paper suggest that the use of course websites in higher education increases students' course satisfaction. The results were in line with the findings of similar studies conducted at majority institutions. The findings illustrate that students enjoyed the use of a course website. The majority of students (92\%) responded that they were satisfied with the use of WebCT; $89.3 \%$ said that they enjoyed the portion of the course on WebCT; and 71\% said that the use of WebCT stimulated their desire to learn. Additionally, the students expressed contentment with both the quantity and quality of their online learning experiences. Although the respondents indicated an overwhelming willingness to enroll in future hybrid courses, a smaller majority said they would take a fully online course in the future.

As a result of this study, one can see that course websites have a positive future in minority education. Future research is needed in this area and these findings have helped to inspire a largescale more in-depth research study. Courses have been be redesigned with mandatory and instructor-led discussions, and expanded content and resources. New instrumentation has been developed that asks more in-depth questions regarding the individual learning components and comparisons will be made between fully online, hybrid, and web-assisted courses. An additional study is also being conducted to measure the technology experiences, uses, and perceptions of incoming students at two different historically black universities and one majority institution.

\section{References}

Allen, I. \& Seaman, J. (2003). Sizing the opportunity: The quality and extent of online education in the United States, 2002-2003. Needham, MA: Sloan.

Berube, D., Murray, C., \& Schultz, K. (1999). Cadaver and computer use in the teaching of gross anatomy in physical therapy education. Journal of Physical Therapy Education, 13(2), 41-46.

Bhatti, A., Tubaisahat, A., \& El-Qawasmeh, E. (2005). Using technology-mediated learning environment to overcome social and cultural limitations in higher education. Issues in Informing Science and Information Technology, 2, 67-76. Available at http://2005papers.iisit.org/I06f77Bhat.pdf

Campos, M. \& Harasim, L. (1999). Virtual-U: Results and challenges of unique field trials. Retrieved May 2005, from the Technology Source Web Site: http://ts.mivu.org/default.asp?show=article\&id=1034

Carnevale, D. (2000). Study assesses what participants look for in high-quality online courses. Chronicle of Higher Education, 47(9), A46.

Carswell, L., Thomas, P., Petre, M., Price, B., \& Richards, M. (2000). Distance education via the internet: the student experience. British Journal of Educational Technology, 31(1, 29-46.

Dziuban, C. \& Moskal, P. (2001). Evaluating distributed learning at metropolitan universities. Educause Quarterly, 24(4), 60-61. 
Hodges, C. (2004) Designing to motivate: Motivational techniques to incorporate in e-learning experience. Journal of Interactive Online Learning. 2(3), 1-7.

Institute of Education Sciences, U.S. Department of Education. (2003). Internet access in U.S. public schools and classrooms: 1994-2002. Retrieved June 29, 2005 from the National Center for Education Statistics Web Site: http://nces.ed.gov/pubs2004/2004022.pdf

Jackson, L., Ervin, K., Gardner, P., \& Schmitt, N. (2001). The racial digital divide: Motivational, affective, and cognitive correlates of Internet use. Journal of Applied Social Psychology, 31(10), 2019-2046.

Koohang, A. \& Harmon, K. (2005). Open source: A metaphor for e-learning. Informing Science Journal, 8, 76-86. Available at http://inform.nu/Articles/Vol8/v8p075-086Kooh.pdf

Lesh, S., Guffey, J., \& Rampp, L. (2000). Changes in student attitudes regarding a web-based health profession course (Reports - Research HE032863). U.S.; Arkansas: Higher Education.

Lewis, B., MacEntee, V., DeLaCruz, S., Englander, C., Jeffrey, T., Takach, E., Wilson, S., \& Woodall, J. (2005). Learning management systems comparison. Proceedings of the 2005 Informing Science and IT Education Joint Conference. Available at http://proceedings.informingscience.org/InSITE2005/P03f55Lewis.pdf

Liu, M., Reed, W., \& Phillips, P. (1992) Teacher education students and computers: Gender, major, prior computer experience, occurrence, and anxiety. Journal of Research on Computing in Education, 24(4), 457-467.

Lorenzetti, J. (2005). Lessons learned about student issues in online learning. Distance Education Report, $9(6), 1-4$.

Martinex, M., \& Mead, N. (1988). Computer competence: The first national assessment (Report No. ETS17-CC-01). Princeton, NJ: National Assessment of Educational Progress. (ERIC No. ED 341 375)

McClintock, R. (1999). Educators manifesto: Renewing the progressive bond with posterity through the social construction of digital learning communities. Published Paper. New York, NY: Teachers College, Columbia University, Institute for Learning Technologies.

Moon, S. (1994). The relationships among gender, computer experience, and attitudes toward computers. Paper presented at the annual meeting of the Mid-South Educational Research Association, Nashville, TN. (ERIC No. ED 381 142)

Morgan, J. \& VanLengen, C. (2005) The digital divide and K-12 student computer usage. Issues in Informing Science and Information Technology, 2, 705-724. Available at http://2005papers.iisit.org/I56f86Morg.pdf

National Telecommunications and Information Administration. (2004). A nation online: Entering the broadband age. Retrieved June 29, 2005 from http://www.ntia.doc/gov/reports/anol/nationonlinebroadband04.htm

Price, R. \& Winiecki, D. (1995). Attitudes and skill levels of college students entering a typical introductory college computing course. Journal of Computing in Teacher Education, 12(1), 20-25.

Rivera, J., McAlister, K., \& Rice, M. (2002). A comparison of student outcomes \& satisfaction between traditional \& web based course offerings. Online Journal of Distance Learning Administration, 5(3), 151-179.

Sanders, D. \& Morrison-Shetlar, A. (2002). Student attitudes toward web-enhanced instruction in an introductory biology course. Journal of Research on Computing in Education, 33(3), 251-262.

Smith, B. \& Necessary, J. (1996). The computer ability scale: Replication and extension involving college computer literacy students. AERA Business Education and Information Sysems Research Special Interest Group proceedings. Washington, DC: American Educational Research Association. (ERIC No. ED 395 218)

Wernet, S., Olliges, R., \& Delicath, T. (2000). Postcourse evaluations of WebCT (Web Course Tools) classes by social work students. Research on Social Work Practice, 10(4), 487-504. 
Incorporating the Hybrid Learning Model

Wu, D. \& Hiltz, R. (2004). Predicting learning from asynchronous online discussions. Journal of Asynchronous Learning Networks, 8(2), 139-152.

Young, J. (2002). "Hybrid" teaching seeks to end the divide between traditional and online instruction. Chronicle of Higher Education, 48(28), A33.

\section{Biographies}

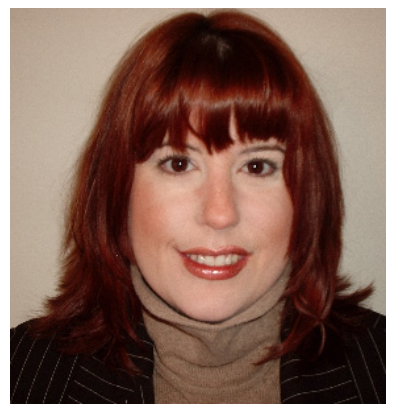

Dr. Nicole A Buzzetto-More has a doctorate in Communications and Instructional Technology from Columbia University, a masters in education in Communications and Instructional Technology from Columbia University, a masters of science in Communications from the College of New Rochelle, and a bachelor of arts degree from Marist College. Originally from New York, she currently resides on the eastern shore of Maryland where she is an Assistant Professor and the Business Education Program Coordinator in the School of Business and Technology at the University of Maryland Eastern Shore. Her intellectual interests include the uses of digital technologies to augment teaching and learning. She holds several grants that support her various instructional technology research and development projects. She has published a number of papers in referred journals and is a frequent presenter at conferences across the globe. In 2005 she was honored by the American Distance Education Consortium. She is currently working on her first book.

Dr. Retta Sweat-Guy has an Ed.D. in Curriculum and Instruction with emphasis in Instructional Systems Design from the University of Kentucky. She received her masters in Public Administration from Kentucky State University and a bachelor of arts degree in Business Education from the University of Kentucky. Currently, she is Assistant Professor in the Department of Marketing and Business Education at Fayetteville State University in Fayetteville, North Carolina. Online teaching and learning serves as the basis for her current research for which she has presented at conferences and in referred publications. She has and continues to conduct workshops and training sessions on the use of web-based course management tools. 